\title{
Study on the Application of Modern Information Technology on College English Writing Teaching
}

\author{
Yingchun Peng ${ }^{1, \text { a }}$ \\ ${ }^{1}$ Jiangxi College of Foreign Studies, Nanchang, Jiang, 330000 \\ ${ }^{a}$ email
}

Keywords: Application, Information Technology, English Teaching

\begin{abstract}
With the rapid development of the information age, information technology has been widely applied to various industries and fields, educators have begun to explore the use and practice in the field of education. Given the traditional college English writing teaching efficiency is not high, and the bad effect caused by the heavy student curriculum teaching of English writing class scarcity issues. Use Microsoft Office Word assisted English writing technologies to replace the original form of writing paper and ink intersect, advocating students to use the Internet technology to support writing in English, using the E -mail technically good online English writing teaching follow-up courses, the technical advantages for PowerPoint English writing, English writing only changed the means of teaching and training, the environment and the teaching process, teachers and students to deepen the relative relationship between teaching and learning, and can effectively improve the level of students' interest in writing and English writing.
\end{abstract}

\section{Introduction}

With the advent of the information age, computer, networking and information dissemination as the representative of the rapid development of modern information technology has revolutionized people's production and living and learning. "Information explosion", "information revolution", "social networking" has become the era of keywords. Multimedia network is changing the transfer mode and information transfer scale, ubiquitous penetration into all aspects of life. We can in the bedroom, libraries, Internet cafes and home through the computer and the network quickly and easily query and retrieval of information; at the same time due to the continuous development of smart phones, tablet PCs and other mobile network terminal, for receiving information and we have not been published limit time and space, anytime, anywhere to access and process information, communicate with others in real time has become a reality. Instant processing of information via the Internet and mobile publishing today not only become part of our daily lives, but we keep up with the times and based on the rapidly changing society an important guarantee. English as an international language, in today's international arena plays an important role. According to relevant statistics, one in five people around the world with varying degrees of English communicative competence; two-thirds of the world's scientists read in English; 80\% of the world's electronic information stored in English; 78\% of the world's website English site. At the same time, communication and exchanges between the academic world more closely, so-called academic Without Borders ... - Training students with some academic English skills, especially English writing ability of students can gain a profound insight into the forefront of the world's academic development, and global academic your peers premise and foundation.

\section{Situation Analysis of University English Writing Teaching}

Writing is a complex language skills, a difficulty for English learners is the most difficult to overcome. Currently in society calling for a high level of English language skills situation 'English teaching profession very seriously improve writing skills of learners, from theory to practice teaching have invested enormous human and material resources, made some gratifying results and progress . However, the fact that our English writing there are still a lot of problems, a lot of the results of theoretical research can not be implemented in teaching practice due to various reasons, 
resulting in the Teaching of English Writing inefficiencies. Specifically, the main problems occur in student writing in English in the following areas:

(1) poor vocabulary, words simple. Students in the writing process, the same word is used throughout express the same meaning, words lack of conversion and change. Writing words showing a "Children's English" (Baby English) and "Chinglish" (Chinglish) phenomenon.

(2) lexical errors. In the writing process, students for synonyms and polysemy lack of knowledge and research in the choice of words and collocation error-prone, and often written and oral vocabulary confused.

(3) a single sentence, the lack of diversification. Among the students writing, simple sentences raw sugar, use throughout the article subject + predicate + object or subject + verb + predicative sentence structure, sentence lacked variety and diversity.

(4) a syntax error. Students often incomplete sentences in the writing process, such as lack of verb; before and after the sentence or not, such as singular and plural change predicate.

(5) Text error. Students of English composition poor content empty, without any substance, "impractical" discourse more. While writing the content and theme of deviation from a "stray" (irrelevant) phenomenon.

(6) logic errors. Mainly for lack of logic error logical relationship between writing paragraphs and paragraphs, there is no logical relationship between the word effectively connect sentences and paragraphs in the sentence, the article structural disorder, the center is not prominent.

Writing is a process of using language to express ideas, but also a social and cultural factors continue to play a role in the process, which involves many fields of linguistics and psychology. Writing factors are many, these factors not only factors involved in teaching, but also includes factors of student learning; involves not only knowledge of the language factor, but also social and cultural background of the factors involved. Way of thinking, students 'writing attitudes, teachers' teaching methods will lead to the process of teaching English writing errors.

\section{Promote Students to Use the Internet Technology to Support English Writing}

Internet information resources is extremely rich. We can say that every aspect of all human knowledge, can be found online, Inter-net like never close global libraries can be shared humanity. This teaching model beginning in the multimedia classroom or instructor-writing process in the existing network of computer classrooms. Also called essay writing training. Before class, teachers need to have a purpose for writing the training topics online search to determine the scope of the article, and the resources at the site. In class, students make their own Internet access, reading filtered articles. In class, allow students to discuss, say the features of the article, the article styles and genres (according to the National CET involved argumentative, expository, practical articles and other types of training topics). At the same time, teachers should remind students learn to focus on articles appear typical usage of vocabulary, sentence structure, rhetorical and stylistic types, and encourage them to be used in imitation of actual writing, which play reading teaching guide students imitative writing guide writing teaching practical effect of writing.

Use of the Internet library database to a read-write and promote English writing teaching methods. Contemporary language input from a theoretical point of view, language users in the reading process, has been constantly receiving the text message. This reading process can be considered a receptive skills, but also take the initiative. It is a reader and the writers of positive interaction. Language experts at home and abroad has always advocated the teaching of writing should build on the basis of reading. This is what we are looking for language input (read) and language output (write) the convergence point. oMoffett said: anyone teach writing of its important tasks is to develop reading awareness, otherwise difficult to learn what effect.

\section{E-Mail Technology is A Follow-Up Courses for Online English Writing}

$\mathrm{E}$-mail is not only the earliest development of the Internet, use the largest number of a service, its fast, easy, cheap and modern means of communication has played an important role in the 
international exchange. The reason why we put Internet technology for the teaching of English writing, because it provides many of the features and multimedia messaging features transfer images, language and video and other information, so that e-mail has become an important means of transmission of multimedia information one. Writing is a form of communication between people, in a real social need operating environment makes sense (Schu \& l Fecho). For college students, this is no real language environment, that is, in English class the student's language and thinking inevitably disturbed mother tongue. The e-mail communications to provide students with a real English communicative context and readers, but also offers the opportunity to experience outside of the classroom in English and use English. In other countries, there are many students like to communicate with their teachers and students with an E -mail, one of the reasons is sent by E-mail written information, they can read most, but with the phone or face to face, they can only understand its meaning but does not know its text, plus everyone's dialect and speech rate issues, increased the difficulty they understand. The second reason, many foreign students to improve their writing skills is to learn from each other's messages in this way, because many authentic expression of words, sentences, verbal communication must be in writing and stuff, especially when transmitting their professional issues and views with $\mathrm{E}$-mail is even more useful. This written communication is also verified the constructivist learning theory: knowledge is derived from the interaction between the cognitive subject and the objective environment, rather than relying on teachers to teach obtained. The theory of the three factors highlighted in the learning environment: 1 . Scenario: learning activities under certain scenarios namely social and cultural background, the learning environment must be conducive to situations students have learned the content of meaning construction. 2. Collaboration: Collaboration has always happened in the learning process, all stages of the learning process have an important role, collaborative person can be a teacher or student. 3 . Constructing Meaning: Meaning Construction is the ultimate goal of the entire learning process. To construct the meaning refers to the intrinsic link the nature of things, law and between things. Email help teacher-student interaction, collaborative learning between students and students, help monitor students' writing process.

Over the years, the number of teachers with classes and more, most of the writing can only give a score can not be performed from deep mark on sentence structure and text, will not achieve to help students enrich the content of the article and the effect of improving the structure of the article. If E -mail way, let students put their writing among students send, and then modify it and then sent through the student to teacher, while others improve student writing has improved himself, but also from someone else personal essay and learn different writing method and style. In addition to teacher E -mail composition for marking, you can also help students to consolidate a number of classroom learning content to students via e-mail, you can recommend some related sites allow students to refer to some of the others writing. By means of this teaching, we can get this kind of teaching Implications: 1 . Increase student between language input, output, and teachers and students, learning opportunities for interaction between students. 2. create real, meaningful learning situations for students writing. 3. To avoid the phenomenon of student teachers are the only readers. 4. During the school you can train university graduates working environment necessary skills.

\section{Conclusion}

We are part of the students' English writing teaching and training reform, and for the teaching practice, the students launched a series of questionnaires. The survey not only to the students of this attitude and improve the degree of teaching mode, but also for teachers teaching awareness, teaching objectives and teaching effectiveness evaluation. Widely felt that modern technology has not only changed the teaching methods of English writing teaching and training, the environment and the teaching process, deepen the relative relationship between teachers teach and students learn, and effectively improve the students' interest in English writing and their writing skills. The use of modern educational technology teacher not only did not feel relaxed, contrary in a better culture methods Students' English Writing, in establishing teaching goals, teaching in modern technology, we must have a new state and a new teaching philosophy. Teachers are the key to the reform of 
teaching English writing, how to use modern information technology to improve language teaching quality education has become an important subject of language teachers.

\section{References}

[1] Belisle, R. Email activities in the ESL writing class [J]. The Internet TESL Journal,Vol. II, No.12, http://iteslj.org/Atricles/BelisleEmail.html, 1996.12.

[2] Bloch, J. Student/Teacher interaction via Email: The social context of internetdiscourse [J]. Journal of Second Language Writing, 2002,(11).

[3] Breuch, Lee-Ann M. Post-process "Pedagogy": A philosophical exercise [J]. JAC: AJournal of Composition Theory, 2002, (1 ).

[4] Ducate, Lara C; Lomicka, Lara L. Exploring the blogosphere: Use of Web Logs inthe foreign language classroom [J]. Foreign Language Annals, 2005(3), Vol.38.

[5] Patsy M. Lightbown \& Nina Spada. How languages are learned [M], Oxford: OxfordUniversity Press, 1997.

[6] Pincas,A- Teaching English Writing [M]. London: Macmillan, 1982. 